間に0.2cc 以下のピークが存在するむのをここで仅り に名付けることにした。形成術而型火認められた。

結論

Wullstein によれば形成術後の治瘾過程が聴力恢復度 飞影響すると．耳管による換気が行われると粘膜炎症の 治澺と新鼓室内の完全な上皮化が起る。この内部の上皮

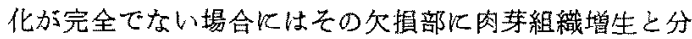

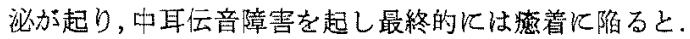
形成術に扔ける耳管機能仙内耳機能化次ぐ要因であり， 前化耳管炎を治瘜できない場合汇は形成術をあきらめる か，あるいは手術によって耳管资香治瘾するであるうの 期待の部倸手術を行うか，どちらかの選択しかないと。

以上の Wullstein の見解添って演者らの術例の TG 所見を娭討するとA型やW型は耳管障害を残さず鼓室内 が完全に上皮化し，従って連鎖の船痕療着を残さなか力 た例でその聴力恢復が正常レベルかそれに近かったこと を赛青している。C型蛙耳管障害の存稅を示し瘾着加連 鎖汇及心゙倾向が大で従ってその德力恢復は $\mathrm{A}$ とW型に比

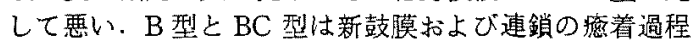
㚙著しい所見と思わ机る。

\section{文献}

Wullstein H.L.：聴力改善手術. 日本語訳, 医学書 院 1979.

Northern J. L. : Selected Readings in Impedance Audiometry. American Electromedics Corporation, 1976.

翼間 熊沢（関西医大）。術後のチンパノメトリーで B，Cタイプを示しても，これは鼓膜の性状による影響が つよく，必ずしも耳管の通気性を示していないと思う。

応答 恩地 豊 B型はC型の上万江耳管障害が娭 出されないがC型が進んだものあるいは新鼓膜が瘾着し たものとしてWullstein の見解炡添って鼓室形成術の成 䒈を批判したのに過きない，耳管障害については熊沢教 授仙素晴しい仾究をして饹られる。その見解加らすると 私の結諭も变え极ばならないと思っている，耳管障害と 帆㚕筋ならびにチンパノグラムの関係について御高説を 承りたい。

(B 82-1009-22182)

\title{
53. Impedance bridge studies on the ears of school children
}

\author{
Jin Myong Soh, Dept. of ENT, Soon Chun Hyang Medical School, Seoul, Korea
}

Early detection of ear diseases has been the main focus of study in the audiological field, and it is true that many children still have never had their hearing defected and treated.

Audiometric test is applied to diagnose middle ear diseases generally, as it thought that middle ear diseases cause hearing impairment and it is easily found by the pure tone audiometric screening method. However, Eagles, Whishik and Doeffler (1967), Fay, et al (1970), Osborn (1970) reported that only $64 \%$ of all conductive pathology cases were detected by pure tone audiometric examination. Considering mild hearing loss in conductive type, ambient noise and troublesome test for infants, it has been considered to develope a more accurate and objective device to test.

On 1940 Metz first described electroacoustic impedance device to test, Thomsen, Anderson, and
Terkildsen learned objective testing method with impedance ten years later, and Onchi emphasized the mechanism of middle ear in the era of 1960 . These principles have become widely utilized since 1970, when Jerger and Liden reported their study with impedance audiometry.

McCandles \& Thomas (1974) reported that impedance bridge was 2.8 times accurate than pure tone audiometry. Brooks (1973) stated that impedance audiometry picked $14 \%$ more of middle ear pathology cases which passed by pure tone audiometry.

Since our country applied the device for clinical examination, we screened school children for the purpose of establishing the standard value of it.

\section{Subjects:}

We had two groups to test. Group I, 1,035 primary and middle school students, aged 7 to 16 , performed the test during July to September 1976. Group II,

Table 1 Age and Sex Distribution

\begin{tabular}{lrrrrrrrrrrrrrr}
\hline Sex & Age & 7 & 8 & 9 & 10 & 11 & 12 & 13 & 14 & 15 & 16 & Total & Ears \\
\hline Male & 18 & 68 & 78 & 72 & 70 & 69 & 64 & 42 & 51 & 5 & 537 & 1074 \\
Female & 19 & 69 & 77 & 59 & 61 & 65 & 39 & 69 & 36 & 4 & 498 & 996 \\
\hline Total & 37 & 137 & 155 & 131 & 131 & 134 & 103 & 111 & 87 & 9 & 1035 & 2070 \\
\hline
\end{tabular}


Table 2 Tympanogram on Clinical Finding

\begin{tabular}{lccc}
\hline & Type A & Type B & Type C \\
\hline Normal & $\begin{array}{c}1840 \\
(88.9 \%)\end{array}$ & $\begin{array}{c}13 \\
(0.63 \%)\end{array}$ & $\begin{array}{c}46 \\
(2.22 \%)\end{array}$ \\
\hline Abnormal & & & \\
Need Tx & 47 & 54 & 22 \\
Not & $(2.27 \%)$ & $(2,61 \%)$ & $(1.06 \%)$ \\
Need Tx & $(2.77 \%)$ & $(0.14 \%)$ & $(0.10 \%)$ \\
\hline
\end{tabular}

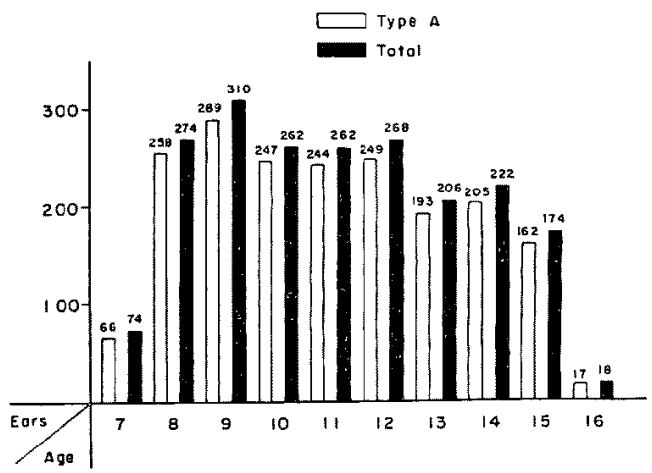

Fig. 1

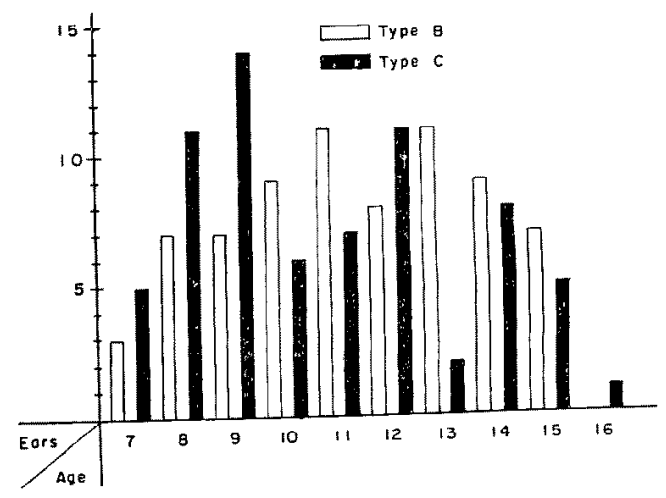

Fig. 2

100 patients, aged 7 to 16 , visited ENT clinic during Feb. 1978 through March 1979 with complaints of hard of hearing and nasal obstruction.

\section{Method:}

The first otoscopic examination was performed to observe middle ear pathology and to remove ear wax to carry on the audiometric test. Teledyne Impedance Audiometer was used to test pure tone screening as well as impedance test.

Results:
Table 3 Age Distribution of Tympanogram

\begin{tabular}{rrrrc}
\hline Age & \multicolumn{1}{c}{ A } & B & C & Total \\
\hline 7 & $66(89.2 \%)$ & 3 & 5 & 74 \\
8 & $258(94.2 \%)$ & 7 & 11 & 274 \\
9 & $289(93.2 \%)$ & 7 & 14 & 310 \\
10 & $247(94.3 \%)$ & 9 & 6 & 262 \\
11 & $244(93.1 \%)$ & 11 & 7 & 262 \\
12 & $249(92.9 \%)$ & 8 & 11 & 268 \\
13 & $193(93.7 \%)$ & 11 & 2 & 206 \\
14 & $205(92.3 \%)$ & 9 & 8 & 222 \\
15 & $162(93.1 \%)$ & 7 & 5 & 174 \\
16 & $17(94.4 \%)$ & 0 & 1 & 18 \\
\hline Total & $1930(93.2 \%)$ & $70(3.4 \%)$ & $70(3.4 \%)$ & $2070(100 \%)$
\end{tabular}

Table 4 Static Compliance of Tympanogram Type A

\begin{tabular}{lr}
\hline Static Compliance & No. of Ears \\
\hline $0.10 \downarrow$ & $121(6.27 \%)$ \\
$0.11 \sim 0.20$ & $451(23.37 \%)$ \\
$0.21 \sim 0.30$ & $513(26.58 \%)$ \\
$0.31 \sim 0.40$ & $325(16.84 \%)$ \\
$0.41 \sim 0.50$ & $204(10.57 \%)$ \\
$0.51 \sim 0.60$ & $117(6.06 \%)$ \\
$0.61 \sim 0.70$ & $56(2.90 \%)$ \\
$0.71 \sim 0.80$ & $42(2.18 \%)$ \\
$0.81 \sim 0.90$ & $26(1.35 \%)$ \\
$0.91 \sim 1.00$ & $13(0.67 \%)$ \\
$1.01 \sim 1.10$ & $15(0.78 \%)$ \\
$1.11 \sim 1.20$ & $11(0.57 \%)$ \\
$1.21 \sim 1.30$ & $9(0.47 \%)$ \\
$1.31 \sim 1.40$ & $7(0.36 \%)$ \\
$1.41 \sim 1.50$ & $1(0.05 \%)$ \\
$1.51 \sim 1.60$ & $5(0.27 \%)$ \\
$1.61 \sim 1.70$ & $4(0.21 \%)$ \\
$1.71 \sim 1.80$ & $10(0.52 \%)$
\end{tabular}

\section{A. Group I}

By otoscopic examination, 1899 ears were shown normal, 123 ears were abnormal, and 48 were found to need treatment. Among normal ears, $88.9 \%$ was shown tympanogram type $A$. Tympanogram type $A$ is 1,930 ears $(93.2 \%)$, type $B$ and $C$ is 70 ears each $(3.4 \%)$. Age distribution of tympanogram shows on Table 3-A. Maximum compliance and initial compliance are increasing in value as the age is growing gradually. At the age of 7 , maximum compliance is $0.98 \mathrm{cc}$ and $2.08 \mathrm{cc}$ at the age of 16 . The initial compliance is $0.69 \mathrm{cc}$ to $1.57 \mathrm{cc}$. Static compliance does not show much increase in yolume and yet still it shows slight increase as the age is getting old. Mean value of the compliance of all children; maxi- 
Table 5 Static Compliance of Tympanogram Type A (1930 Cases)

\begin{tabular}{|c|c|c|}
\hline 0.05 & $\begin{array}{c}0.07 \cdots \cdots 0.34 \cdots \cdots 1.09 \\
95 \% \\
99 \%\end{array}$ & $\begin{array}{l}1.71 \\
\left.\right|^{1}\end{array}$ \\
\hline
\end{tabular}

Table 6 Mean Value of Compliance on Age

\begin{tabular}{rccc}
\hline Age & $\begin{array}{c}\text { Comp. } \\
\text { Coximum }\end{array}$ & $\begin{array}{c}\text { Initial } \\
\text { Comp. }\end{array}$ & $\begin{array}{c}\text { Static } \\
\text { Comp. }\end{array}$ \\
\hline 7 & 0.98 & 0.69 & 0.29 \\
8 & 1.04 & 0.72 & 0.32 \\
9 & 1.08 & 0.77 & 0.31 \\
10 & 1.20 & 0.84 & 0.36 \\
11 & 1.19 & 0.85 & 0.34 \\
12 & 1.18 & 0.83 & 0.35 \\
13 & 1.30 & 0.97 & 0.33 \\
14 & 1.45 & 1.11 & 0.34 \\
15 & 1.80 & 1.41 & 0.39 \\
16 & 2.08 & 1.57 & 0.51 \\
\hline Total & 1.24 & 0.90 & 0.34 \\
\hline
\end{tabular}

Table 7 (dB) Stapedial Reflex Threshold

\begin{tabular}{rrrrrr}
\hline $\mathrm{Hz}$ Age & $7 \sim 9$ & $10 \sim 11$ & $12 \sim 13$ & $14 \sim 16$ & Ave. \\
\hline 500 & 97.7 & 98.8 & 95.4 & 89.4 & 95.6 \\
1000 & 98.9 & 98.6 & 96.2 & 96.9 & 96.2 \\
2000 & 98.1 & 98.5 & 96.6 & 90.5 & 96.2 \\
4000 & 98.5 & 98.5 & 96.7 & 90.8 & 06.4 \\
\hline
\end{tabular}

Table 8 Classification by Chief Complaints

Nasal obstruction: 25 cases

Hard of Hearing: " 75 cases

Table 9 Sex and Age Distribution

\begin{tabular}{lrrrrrrrrrrrr}
\hline Sex Age & 7 & 8 & 9 & 10 & 11 & 12 & 13 & 14 & 15 & 16 & Total \\
\hline Male & 17 & 10 & 8 & 3 & 2 & 7 & 3 & 6 & 2 & 6 & 64 \\
Female & 7 & 3 & 6 & 6 & 5 & 1 & 3 & 1 & 1 & 3 & 36 \\
\hline Total & 24 & 13 & 14 & 9 & 7 & 8 & 6 & 7 & 3 & 9 & 100 \\
\hline
\end{tabular}

Table 10 Tympanogram and Otoscopic Ex. on the Nasal Obstruction Patients

\begin{tabular}{rrrr}
\hline & Drum intact & Not intact \\
\hline Type A & $25(51.02 \%)$ & $3(6.12 \%)$ \\
B & $4(8.16 \%)$ & $13(26.53 \%)$ \\
C & $2(4.08 \%)$ & $2(4.08 \%)$ \\
\hline
\end{tabular}

Table 11 Tympanogram and Otoscopic Ex. on the Hard of Hearing Patients

\begin{tabular}{rrrr} 
& & Drum intact & Not intact \\
\hline Type A & $50(33.56 \%)$ & $19(12.75 \%)$ \\
B & $16(10.73 \%)$ & $53(35.57 \%)$ \\
C & $5(3.36 \%)$ & $6(4.02 \%)$ \\
\hline
\end{tabular}

Table 12 Static Compliance of Type A in Nasal Obstruction

\begin{tabular}{lccccccccccc}
\multicolumn{1}{c}{ Age } & 7 & 8 & 9 & 10 & 11 & 12 & 13 & 14 & 15 & 16 & $\begin{array}{c}\text { Mean } \\
\text { value }\end{array}$ \\
\hline Max. compliance & 1.70 & 1.66 & 1.81 & none & 1.49 & 1.05 & 1.73 & none & 2.27 & 1.53 & 1.66 \\
Ini. compliance & 1.20 & 1.0 & 1.44 & & 1.18 & 0.76 & 1.12 & & 1.66 & 1.18 & 1.19 \\
Static compliance & 0.50 & 0.66 & 0.38 & & 0.31 & 0.29 & 0.61 & & 0.62 & 0.35 & 0.47 \\
\hline
\end{tabular}

Table 13 Static Compliance of Type A in Hard of Hearing

\begin{tabular}{lcccccccccccc}
\hline Age & 7 & 8 & 9 & 10 & 11 & 12 & 13 & 14 & 15 & 16 & $\begin{array}{c}\text { Mean } \\
\text { value }\end{array}$ \\
\hline Max. compliance & 1.39 & 1.75 & 1.43 & 1.62 & 1.64 & 1.52 & 2.04 & 2.24 & 3.27 & 1.76 & 1.87 \\
Ini-compliance & 1.06 & 1.36 & 1.04 & 1.20 & 1.22 & 0.96 & 1.51 & 1.63 & 2.33 & 1.36 & 1.37 \\
Static compliance & 0.33 & 0.39 & 0.39 & 0.42 & 0.42 & 0.56 & 0.53 & 0.61 & 0.94 & 0.40 & 0.50 & \\
\hline
\end{tabular}

mum compliance is $1.24 \mathrm{cc}$, initial compliance is $0.90 \mathrm{cc}$ and static compliance shows $0.34 \mathrm{cc}$.

It shows most cases of static compliance are be- tween $0.10 \mathrm{cc}$ to $1.00 \mathrm{cc}$, and 121 ears $(9.27 \%)$ are below $0.10 \mathrm{cc}$, which are far below Brooks, Feldman, and Jerger's value. It is hard to conclude. Korean 
Table 14 Static Compliance

\begin{tabular}{cc}
\hline Static compliance & No. of Ear $(\%)$ \\
\hline $0.10 \downarrow$ & $0(0 \%)$ \\
$0.11 \sim 0.20$ & $3(3.09 \%)$ \\
$0.21 \sim 0.30$ & $22(22.68 \%)$ \\
$0.31 \sim 0.40$ & $18(18.56 \%)$ \\
$0.41 \sim 0.50$ & $18(18.56 \%)$ \\
$0.51 \sim 0.60$ & $16(16.49 \%)$ \\
$0.61 \sim 0.70$ & $7(7.22 \%)$ \\
$0.71 \sim 0.80$ & $5(5.15 \%)$ \\
$0.81 \sim 0.90$ & $4(4.12 \%)$ \\
$0.91 \sim 1.00$ & $2(2.06 \%)$ \\
$1.01 \sim 1.10$ & $1(1.03 \%)$ \\
$1.11 \sim 1.20$ & $0(0 \%)$ \\
$1.21 \sim 1.30$ & $0(0) \%)$ \\
$1.31 \sim 1.40$ & $0(0) \%)$ \\
$1.41 \sim 1.50$ & $1(1.03 \%)$ \\
\hline Total & $97(100 \%)$ \\
\hline
\end{tabular}

Table 15 Stapedius Reflex Threshold

\begin{tabular}{ccccc}
\hline site frequency & 500 & $1 \mathrm{~K}$ & $2 \mathrm{~K}$ & $4 \mathrm{~K}$ \\
\hline Rt. & 95.31 & 97.65 & 96.0 & 95.44 \\
Lt. & 95.44 & 96.62 & 96.0 & 96.42 \\
\hline
\end{tabular}

Table 16

\begin{tabular}{|c|c|c|c|c|}
\hline & Static Complir & ance & Reflex & \\
\hline Robertson, 1968 & & Ciff & rence be & etween \\
\hline & & & $\begin{array}{c}18 \mathrm{~m}+ \\
(65 \mathrm{~dB}\end{array}$ & $\begin{array}{l}+ \text { adult } \\
3 \text { SPL) }\end{array}$ \\
\hline & & & $500 \quad 11$ & $1.9 \mathrm{~dB}$ \\
\hline & & & $1 \mathrm{~K}$ & $7.1 \mathrm{~dB}$ \\
\hline & & & $2 \mathrm{~K}$ & $7 \mathrm{~dB}$ \\
\hline Brooks, 1969 & $0.35 \sim 1.40$ & $95 \%$ & & \\
\hline & $0.28 \sim 1.72$ & $99 \%$ & & \\
\hline Alberti \& & $5 \sim 10$ yrs & 0.61 & & \\
\hline Kristensen, 1972 & (mean $\mathrm{v}$ & value) & & \\
\hline Mc Candle, 1972 & $0.35 \sim 1.37$ & & & \\
\hline Keith, 1973 & $0.25 \sim 1.65$ & infant & & \\
\hline Jerger, 1974 & $>6$ yrs 0.55 & $5 \mathrm{cc}$ & $>3$ yrs & 95.5 \\
\hline & & & $5 \mathrm{yrs}$ & 89.5 \\
\hline
\end{tabular}

childron's static compliance is lower than Caucasians as they reported, and further investigation is advised. With the 99 percentile is $0.07 \mathrm{cc}$ to $1.09 \mathrm{cc}$.

STAPEDIAL REFLEX: Its value is accounted as shown on as by table 7 . These are tested with $30 \mathrm{~dB}$ pure tone on $500 \mathrm{~Hz}, 1,000 \mathrm{~Hz}, 2,000 \mathrm{~Hz}$ and $4,000 \mathrm{~Hz}$ on 1,267 ears the age of 7 to 9,10 to 11 ,
12 to 13 , and 14 to 16 . Each value shows $95.6 \mathrm{~dB}$, $96.2 \mathrm{~dB}$, and $96.2 \mathrm{~dB}$ and $96.4 \mathrm{~dB}$, average $96.1 \mathrm{~dB}$.

B. Group II

25 children with complaints of nasal obstruction and 75 children with complaints of hard of hearing were analysed. Among the nasal obstruction patients, tympanogram type $B$ was shown 17 ears, and type $C$ is 4 ears. 69 ears with tympanogram type $A$ are shown among the patients with the complaints of hard of hearing, 69 ears with type B and 11 ears with type $\mathrm{C}$.

The static compliance of type $A$ on the patients with nasal obstruction and hard of hearing was shown along the age group on table 12, 13. Their mean values are $0.47 \mathrm{cc}$ and $0.50 \mathrm{cc}$. As a whole, the value is exhibited between $0.11 \mathrm{cc}$ to $1.10 \mathrm{cc}$ as 99 percentile.

The stapedial refiex threshold is represented as mean value $95.38 \mathrm{~dB}$ on $500 \mathrm{~Hz}, 97.14 \mathrm{~dB}$ on $1,000 \mathrm{~Hz}$, $96.0 \mathrm{~dB}$ on $2,000 \mathrm{~Hz}$, and $95.93 \mathrm{~dB}$ on $4,000 \mathrm{~Hz}$.

\section{Discussion}

It has been well known that impedance audiometry has shown. remarkable progress in the audiological feld, and has stimulated much in research of hearing because of its handy and objective quality.

Brooks reported on the static compliance $0.35 \mathrm{cc}$ to $1.40 \mathrm{cc}$ on $95 \%$ and $0.28 \mathrm{cc}$ to $1.72 \mathrm{cc}$ on $99 \%$. Alberti and Kristensen mean value of static compliance at the age between 5-10 yrs old $0.6 \mathrm{cc}$. McCandle reported $0.35 \mathrm{cc}$ to $1.37 \mathrm{cc}$, and Keith learned $0.25 \mathrm{cc}$ to $1.65 \mathrm{cc}$ in infant. Jerger stated $0.55 \mathrm{cc}$ in children aged less than 6 years old.

On the stapedial reflex threshold, Robertson learned the difference between age of 18 months to adult on the $65 \mathrm{~dB} \mathrm{SPL}, 11.9 \mathrm{~dB}$ on $500 \mathrm{~Hz}, 7.1 \mathrm{~dB}$ on $1,000 \mathrm{~Hz}$, and $7 \mathrm{~dB}$ on $2,000 \mathrm{~Hz}$. Jerger reported $95.5 \mathrm{~dB}$ at the age less than 3 and $89.5 \mathrm{~dB}$ at the age of 5 .

Our data of static compliance is much smaller than their reports through reflex threshold is shown similar value.

\section{Conelusion}

1. Range of static compliance in school children is $0.09 \mathrm{cc} \sim 1.7 \mathrm{cc}$ in $99 \%, 0.07 \mathrm{cc} \sim 1.09 \mathrm{cc}$ in $95 \%$, and hospital group show $0.11 \mathrm{cc} \sim 1.10 \mathrm{cc}$ in $99 \%$.

2. Stapedial Reflex threshold is;

$\begin{array}{ccc} & \text { School group } & \text { Hospital group } \\ 500 & 95.6 & 95.4 \\ 1 \mathrm{~K} & 96.2 & 97.1 \\ 2 \mathrm{~K} & 96.2 & 96.0 \\ 4 \mathrm{~K} & 96.4 & 95.9\end{array}$

3. In school children, screening learns tympanogram type $\mathrm{A}$ is $93.2 \%$, type $\mathrm{B}$ is $3.4 \%$, and type $\mathrm{C}$ is $3.4 \%$

(B 82-1010-22582) 